\title{
EFEKTIVITAS MODEL PEMBELAJARAN DISCOVERY LEARNING DAN PROBLEM BASED LEARNING DITINJAU DARI HASIL BELAJAR MATEMATIKA SISWA PADA MATERI TURUNAN
}

\author{
Ayu Jumiarti ${ }^{1)}$ \\ Ariantje Dimpudus ${ }^{2)}$ \\ Haeruddin $^{3)}$ \\ ${ }^{1), 2), 3)}$ Program Studi Pendidikan Matematika, Universitas Mulawarman \\ Email: ${ }^{1)}$ ayujumiarti2706@gmail.com ${ }^{2)}$ ariantjemath@gmail.com \\ ${ }^{3)}$ haeruddin22@gmail.com
}

\begin{abstract}
ABSTRAK
Penelitian ini merupakan penelitian eksperimen semu yang bertujuan untuk mengetahui efektivitas model pembelajaran discovery learning dan problem based learning pada materi turunan di kelas XI SMA Negeri 3 Samarinda tahun ajaran 2019/2020 dan untuk mengetahui apakah terdapat perbedaan hasil belajar matematika siswa yang diajar dengan model discovery learning, problem based learning, dan pembelajaran langsung. Populasi dalam penelitian ini adalah siswa kelas XI IPA SMA Negeri 3 Samarinda tahun ajaran 2019/2020. Dengan teknik sampling purposive, dipilih siswa kelas XI IPA 1, XI IPA 2, dan XI IPA 3 yang masing-masing sebanyak 35 siswa sebagai sampel penelitian. Instrumen dalam penelitian ini adalah tes tertulis yang berbentuk soal uraian yang berjumlah 8 butir dengan skor maksimal 100. Analisis data menggunakan statistik deskriptif dan uji anova satu arah yang kemudian dilanjutkan dengan uji Least Significant Difference (LSD) dengan taraf signifikansi 5\%. Diperoleh kesimpulan bahwa model discovery learning dan problem based learning efektif digunakan pada materi turunan di kelas XI SMA Negeri 3 Samarinda tahun ajaran 2019/2020. Serta diperoleh kesimpulan bahwa tidak terdapat perbedaan hasil belajar antara model discovery learning dan problem based learning, namun terdapat perbedaan hasil belajar antara model discovery learning dan pembelajaran langsung serta antara model problem based learning dan pembelajaran langsung.
\end{abstract}

Kata kunci: Efektivitas, Hasil Belajar Matematika, Discovery learning, Problem based learning

\section{ABSTRACT}

This research is an experimental research that aims to determine the effectiveness of discovery learning and problem-based learning models on derived material in class XI SMA Negeri 3 Samarinda in the 2019/2020 school year and to find out whether there are differences in student mathematics learning outcomes taught by the discovery learning model, problem based learning, and direct learning. The population in this study were students of class XI IPA SMA Negeri 3 Samarinda in the 2019/2020 school year. With a purposive sampling technique, students selected class XI IPA 1, XI IPA 2, and XI IPA 3 , each of which was 35 students as the research sample. The instrument in this study was a 
written test in the form of essay questions totaling 8 items with a maximum score of 100 . Data analysis used descriptive statistics and one-way ANOVA test which was then followed by the Least Significant Difference (LSD) test with a significance level of $5 \%$. The conclusion is that discovery learning and problem-based learning models are effectively used in derived material in class XI SMA Negeri 3 Samarinda in the 2019/2020 school year. And the conclusion is that there is no difference between the discovery learning model and the problem based learning model, but there is a difference between the discovery learning model and direct learning and between the problem based learning model and direct learning.

Keywords: Effectiveness, Mathematics Learning Outcomes, Discovery learning, Problem based learning

\section{PENDAHULUAN}

Dalam proses pembelajaran, siswa sebagai objek sangat diharapkan mampu memahami apa yang diajarkan. Terutama dalam mata pelajaran matematika karena matematika merupakan salah satu pelajaran pokok yang memegang memegang peranan penting, baik pola pikirnya dalam membentuk siswa berkualitas maupun terapannya dalam kehidupan sehari-hari. Namun tidak dapat dipungkiri melihat kenyataan yang terjadi di lapangan, nyatanya banyak siswa yang kurang menguasai materi yang diajarkan. Siswa hanya melihat, mendengar, serta mencatat apa yang dijelaskan oleh guru. Siswa kurang aktif dalam mengerjakan soal-soal, siswa malu bertanya tentang materi yang belum dipahami, dan saat diberikan tes $83 \%$ siswa belum mencapai KKM (Kriteria Ketuntasan Minimum) yang ditetapkan sekolah, yakni 75 .

Berdasarkan observasi selama Pengenalan Lapangan Persekolahan (PLP) yang dilaksanakan mulai tanggal 22 Juli-2 November 2019, peneliti melihat pembelajaran yang dominan dilakukan guru adalah pembelajaran langsung, dimana guru menjadi pusat pembelajaran. mengikuti pelajaran matematika belum tampak, siswa jarang mengajukan pertanyaan meskipun telah dipersilakan untuk bertanya, sehingga ketika diberikan tes, rata-rata hasil belajar matematika siswa kelas XI tersebut masih kurang karena belum mencapai nilai 75 yang dijadikan standar KKM oleh sekolah.

Sitio (2016:3) menyatakan bahwa rendahnya hasil belajar siswa dapat dipengaruhi oleh penggunaan model pembelajaran yang kurang bervariasi. Jika guru mampu mendesain pembelajaran dengan model dan media yang sesuai, maka masih terdapat peluang untuk guru dapat mengatasi permasalahan yang sedang terjadi dalam proses pembelajaran.

Materi-materi dalam pelajaran matematika memerlukan keaktifan siswa, salah satunya adalah materi turunan. Materi turunan bukanlah suatu materi hafalan, sehingga jika siswa belum menguasai konsepnya maka siswa akan kesulitan dalam menyelesaikan soal-soal yang diberikan. Selain itu, materi turunan merupakan materi prasyarat untuk materi integral, maka penguasaan dalam materi turunan sangat diperlukan untuk menunjang penguasaan materi integral. 
Pelaksanaan pendidikan di Indonesia tidak terlepas dari pedoman dalam pelaksanaan pendidikan, yakni kurikulum. Saat ini Indonesia menganut kurikulum 2013. Menurut Kurniawan dan Noviana (2017:390), prinsip utama yang mendasar pada kurikulum 2013 adalah penekanan pada kemampuan seorang guru dalam mengimplementasikan proses pembelajaran yang otentik, menantang dan bermakna bagi peserta didik sehingga dengan demikian dapatlah berkembang potensi peserta didik sesuai dengan apa yang diharapkan oleh tujuan pendidikan nasional. Menurut Fauziah (dalam Susilawati dan Hidayat, 2016:61) proses pembelajaran dalam kurikulum 2013 untuk semua jenjang dilaksanakan dengan menggunakan pendekatan scientifik yatu pendekatan pembelajaran yang berpusat pada siswa, proses pembelajaran yang sesuai dengan pendekatan ilmiah.

Salah satu model pembelajaran yang saat ini banyak digunakan untuk meningkatkan keaktifan siswa sehingga proses belajar mengajar tidak lagi berpusat pada guru, melainkan berpusat pada aktivitas siswa itu sendiri adalah model pembelajaran discovery learning. Menurut Kemendikbud (2017:11) model pembelajaran discovery learning adalah model pembelajaran yang memberikan kesempatan kepada siswa untuk menyingkap atau mencari tahu tentang suatu permasalahan atau sesuatu yang sebenarnya ada namun belum mengemuka dan menemukan solusinya berdasarkan hasil pengolahan informasi yang dicari dan dikumpulkan sendiri, sehingga siswa memiliki pengetahuan baru yang dapat digunakannya dalam memecahkan persoalan yang relevan dalam kehidupan sehari-hari.

Model pembelajaran lain yang berpusat pada siswa adalah model pembelajaran berbasis masalah atau dikenal dengan problem based learning. pembelajaran berbasis masalah bertujuan mendorong siswa untuk belajar melalui berbagai permasalahan nyata dalam kehidupan sehari-hari, atau permasalahan yang dikaitkan dengan pengetahuan yang telah atau akan dipelajarinya.

Beberapa penelitian terdahulu berhasil membuktikan bahwa terdapat perbedaan hasil belajar matematika menggunakan model pembelajaran discovery learning dan problem based learning. Suminar dan Meilani (2016:87) melakukan penelitian tentang pengaruh model pembelajaran discovery learning dan problem based learning terhadap prestasi belajar peserta didik. Hasil penelitian ini menunjukkan bahwa model pembelajaran discovery learning lebih efektif digunakan daripada model pembelajaran problem based learning.

Di sisi lain, Nurochim dan Prihatnani (2018:146) melakukan penelitian tentang perbedaan penerapan model problem based learning dan discovery learning ditinjau dari hasil belajar matematika. Penelitian tersebut memberikan hasil yang berbeda dengan penelitian Suminar dan Meilani, dimana hasilnya menunjukkan bahwa hasil belajar matematika menggunakan model problem based learning lebih tinggi daripada menggunakan model discovery learning.

Adanya perbedaan hasil penelitian tersebut semakin memperkuat keinginan penulis untuk melakukan penelitian guna membandingkan efektifitas model 
pembelajaran problem based learning dan discovery learning terhadap hasil belajar matematika di kelas XI SMA Negeri 3 Samarinda.

\section{METODE PENELITIAN}

Penelitian ini merupakan penelitian eksperimen semu (Quasi Eksperiment) dengan desain posttest only control group design. Penulis melakukan penelitian di tiga kelompok dengan kemampuan yang sama yaitu satu kelompok kontrol yang diajar dengan model pembelajaran langsung, dan dua kelompok eksperimen yang masing-masing diajar dengan model discovery learning dan problem based learning. Penelitian dilaksanakan pada bulan Maret 2020 di SMA Negeri 3 Samarinda. Populasi dalam penelitian ini adalah siswa kelas XI IPA SMA Negeri 3 Samarinda yang terdiri dari 6 kelas yaitu kelas XI IPA 1 sampai dengan XI IPA 6. Dari populasi tersebut dipilih sampel dengan menggunakan teknik sampling purposive yaitu teknik pemilihan sampel dengan pertimbangan tertentu. Pertimbangan yang dilakukan adalah dengan memilih kelas yang memiliki kemampuan yang relatif sama. Berdasarkan nilai hasil ulangan semester ganjil 2019/2020 dipilih tiga kelas yang memiliki kemampuan yang relatif sama yakni kelas XI IPA 1, kelas XI IPA 2 dan kelas XI IPA 3.

Data yang dikumpulkan dalam penelitian ini berasal dari:

1. Lembar Observasi Keterlaksanaan Pembelajaran

Butir-butir instrumen mengacu pada langkah-langkah pembelajaran discovery learning dan problem based learning yang disesuaikan RPP.
Pengamatan dilakukan oleh dua orang observer.

2. Lembar Observasi Aktivitas Siswa

Lembar observasi aktivitas siswa yang digunakan terdiri dari 10 indikator observasi.

3. Tes Hasil Belajar

Bentuk tes yang digunakan adalah soal uraian berjumlah 8 butir soal dengan materi pokok Turunan.

Data yang telah dikumpulkan selanjutnya dianalisis dengan teknik analisis statistik deskriptif dan inferensial sebagai berikut:

1. Analisis Statistik Deskriptif

a) Hasil Belajar Matematika

Kategori yang digunakan untuk menentukan ketuntasan hasil belajar siswa dapat diberikan pada Tabel 1.

Tabel 1. Kategori Standar Ketuntasan Hasil Belajar Siswa

\begin{tabular}{|c|l|}
\hline $\begin{array}{c}\text { Tingkat } \\
\text { Penguasaan }\end{array}$ & $\begin{array}{c}\text { Kategori Ketuntasan } \\
\text { Belajar }\end{array}$ \\
\hline $0 \leq x<75$ & Tidak Tuntas \\
\hline $75 \leq x \leq 100$ & Tuntas \\
\hline
\end{tabular}

Dalam penelitian ini yang digunakan adalah rata-rata kelas nilai hasil belajar matematika siswa untuk mengetahui tingkat ketercapaian efektivitas model pembelajaran yang digunakan, sebagaimana kriteria seperti pada Tabel 2.

Tabel 2. Kategori Standar Keefektifan Model Pembelajaran

\begin{tabular}{|c|l|}
\hline $\begin{array}{c}\text { Tingkat } \\
\text { Penguasaan }\end{array}$ & $\begin{array}{c}\text { Kategori Keefektifan } \\
\text { Model Pembelajaran }\end{array}$ \\
\hline $0 \leq \bar{X}<75$ & Tidak Efektif \\
\hline $75 \leq \bar{X} \leq 100$ & Efektif \\
\hline
\end{tabular}


b) Aktivitas Siswa

Kriteria keberhasilan aktivitas siswa dalam penelitian ini dikatakan efektif apabila minimal $70 \%$ siswa terlibat aktif dalam proses pembelajaran.

c) Keterlaksanaan Pembelajaran

Teknik analisis data untuk keterlaksanaan pembelajaran adalah analisis rata-rata. Adapun pengkategorian keterlaksanaan model pembelajaran digunakan kategori seperti dalam Tabel 3.

Tabel 3. Konversi Nilai Keterlaksanaan Pembelajaran

\begin{tabular}{|c|l|}
\hline Interval skor & Kategori \\
\hline $4,50<\bar{X} \leq 5,00$ & Sangat Baik \\
\hline $3,50<\bar{X} \leq 4,50$ & Baik \\
\hline $2,50<\bar{X} \leq 3,50$ & Kurang baik \\
\hline $1,50<\bar{X} \leq 2,50$ & Tidak baik \\
\hline $1,00<\bar{X} \leq 1,50$ & Sangat Tidak baik \\
\hline
\end{tabular}

Sumber: Widyoko (2009)

\section{Analisis Statistik Inferensial}

a) Uji Anova satu arah

Pasangan hipotesis statistik dalam penelitian ini adalah sebagai berikut:

$H_{0}: \mu_{1}=\mu_{2}=\mu_{3}$

$H_{1}: \mu_{i} \neq \mu_{j}$, untuk minimal satu pasang $(i, j)$.

Dalam penelitian ini, analisis varian satu arah dibantu dengan program SPSS. Kriteria pengujian yaitu:

$H_{0}$ diterima jika $F_{\text {hitung }} \leq$ $F_{\text {tabel }}\left(v_{1}, v_{2}\right)$ atau $p \geq a$ dan sebaliknya

$H_{1}$ diterima jika $F_{\text {hitung }}>$ $F_{\text {tabel }}\left(v_{1}, v_{2}\right)$ atau $p<a$ Bila $\mathrm{H}_{1}$ diterima berarti terdapat respon yang berbeda dari bermacam- macam perlakuan atau dengan kata lain bila $\mathrm{H}_{0}$ ditolak berarti minimal terdapat sepasang pelakuan yang berbeda.

b) Uji Lanjut Least Significant Difference (LSD)

Uji LSD menggunakan perbandingan berbagai rata-rata dengan uji $t$ untuk mengetahui perbedaan dari pasangan ratarata. Uji LSD dapat dihitung menggunakan rumus:

$$
L S D=t_{\alpha(d b)} \sqrt{\frac{2 K T_{\text {sisa }}}{\text { Ulangan }}}
$$

Dalam penelitian ini, peneliti menggunakan bantuan komputer dengan program SPSS. Adapun hipotesis dalam uji ini adalah:

$H_{0}: \mu_{i}=\mu_{j}$

$H_{1}: \mu_{i} \neq \mu_{j}$ untuk minimal satu pasang

$(\mathrm{i}, \mathrm{j})$

\section{HASIL PENELITIAN DAN PEMBA-} HASAN

Berdasarkan hasil penelitian di SMA Negeri 3 Samarinda yag dilaksanakan pada bulan maret 2020, diperoleh hasil belajar matematika dengan deskripsi seperti pada Tabel 4. Berdasarkan Tabel 4, hasil belajar matematika siswa pada kelas yang diajar dengan model discovery learning dan kelas yang diajar dengan model problem based learning telah mencapai kriteria ketuntasan minimum (KKM) yaitu 75 dengan rata-rata nilai kelas discovery learning sebesar 78,89 dan rata-rata nilai kelas problem based learning sebesar 76,09 . 
Tabel 4. Deskripsi Hasil Belajar Matematika

\begin{tabular}{|c|c|c|c|}
\hline Statistik & $\begin{array}{c}\text { Pembelajaran } \\
\text { langsung }\end{array}$ & $\begin{array}{c}\text { Discovery } \\
\text { learning }\end{array}$ & $\begin{array}{c}\text { Problem based } \\
\text { learning }\end{array}$ \\
\hline Sampel & 35 & 35 & 35 \\
\hline Nilai tertinggi & 85 & 91 & 90 \\
\hline Nilai terendah & 46 & 44 & 49 \\
\hline Rentang nilai & 39 & 47 & 41 \\
\hline Standar deviasi & 11,06 & 9,48 & 9,31 \\
\hline Rata-rata nilai & 64,31 & 78,89 & 76,09 \\
\hline
\end{tabular}

Dengan demikian dapat dikatakan Adapun Rata-rata hasil belajar bahwa model pembelajaran discovery matematika siswa dari ketiga kelas learning dan problem based learning tersebut sesuai dengan hasil pengamatan efektif digunakan pada materi turunan di aktivitas siswa yang dilakukan oleh guru kelas XI SMA Negeri 3 Samarinda.

Sedangkan rata-rata nilai kelas yang diajar dengan pembelajaran langsung masih kurang dari kriteria ketuntasan minimum $(\mathrm{KKM})$ yaitu $64,31<75$. dengan deskripsi hasil pengamatan aktivitas siswa yang diajar dengan menggunakan model discovery learning dan problem based learning masingmasing disajikan dalam Tabel 5.

Tabel 5. Hasil Pengamatan Aktivitas Siswa

\begin{tabular}{|c|c|c|c|c|c|}
\hline \multirow{2}{*}{ No } & \multirow{2}{*}{ Aktivitas Yang Diamati } & \multicolumn{2}{|c|}{ Discovery learning } & \multicolumn{2}{|c|}{$\begin{array}{l}\text { Problem based } \\
\text { learning }\end{array}$} \\
\hline & & $\begin{array}{l}\text { Rata- } \\
\text { rata }\end{array}$ & $\begin{array}{l}\text { Persentase } \\
\quad(\%)\end{array}$ & $\begin{array}{l}\text { Rata- } \\
\text { rata }\end{array}$ & $\begin{array}{c}\text { Persentase } \\
(\%)\end{array}$ \\
\hline A & \multicolumn{5}{|l|}{ KEGIATAN PENDAHULUAN } \\
\hline 1 & Siswa hadir pada saat pembelajaran & 34 & 97,14 & 33 & 94,28 \\
\hline 2 & $\begin{array}{l}\text { Siswa memusatkan perhatian pada } \\
\text { materi yang akan dipelajari }\end{array}$ & 29 & 82,86 & 31 & 88,57 \\
\hline B & \multicolumn{5}{|l|}{ KEGIATAN INTI } \\
\hline 1 & $\begin{array}{l}\text { Siswa bertanya tentang materi yang } \\
\text { belum dipahami }\end{array}$ & 17 & 48,57 & 17 & 48,57 \\
\hline 2 & $\begin{array}{l}\text { Siswa menjawab pertanyaan yang } \\
\text { diajukan oleh guru atau teman }\end{array}$ & 14 & 40 & 19 & 54,29 \\
\hline 3 & $\begin{array}{l}\text { Siswa mengemukakan pendapat } \\
\text { kepada guru atau teman }\end{array}$ & 16 & 45,71 & 17 & 48,57 \\
\hline 4 & $\begin{array}{l}\text { Siswa mempresentasikan hasil } \\
\text { jawaban di depan kelas }\end{array}$ & 34 & 97,14 & 33 & 94,28 \\
\hline $\mathrm{C}$ & \multicolumn{5}{|l|}{ KEGIATAN PENUTUP } \\
\hline 1 & Siswa merangkum materi pelajaran & 32 & 91,43 & 32 & 91,43 \\
\hline 2 & $\begin{array}{l}\text { Siswa mendengarkan dan } \\
\text { memperhatikan penjlasan, arahan, } \\
\text { dan motivasi yang disampaikan } \\
\text { guru sebelum pembelajaran berakhir }\end{array}$ & 31 & 88,57 & 32 & 91,43 \\
\hline & Rata-rata total & 25,88 & 73,93 & 26,9 & 76,43 \\
\hline
\end{tabular}


Berdasarkan Tabel 5, rata-rata keseluruhan indikator untuk kelas discovery learning adalah 25,88 dengan persentase sebesar $73,93 \%$ dan rata-rata untuk kelas problem based learning adalah 26,9 dengan persentase sebesar $76,43 \%$. Kriteria keberhasilan aktivitas siswa dalam model discovery learning dan problem based learning dikatakan efektif karena persentase keaktifan siswa $>70 \%$. Demikian pula dengan hasil pengamatan keterlaksanaan pembelajaran yang dilakukan oleh dua orang pengamat, dimana hasil pengamatan tersebut sesuai dengan hasil belajar matematika siswa yang diperoleh. Adapun hasil pengamatan dari kedua pengamat dengan dua model yang berbeda dapat dilihat pada Tabel 6 .

Tabel 6. Data Hasil Pengamatan Keterlaksanaan Pembelajaran

\begin{tabular}{|c|c|c|c|c|}
\hline \multirow{2}{*}{$\begin{array}{c}\text { Pertemuan } \\
\text { ke- }\end{array}$} & \multicolumn{2}{|c|}{ Discovery learning } & \multicolumn{2}{c|}{ Problem based learning } \\
\cline { 2 - 5 } & Pengamat 1 & Pengamat 2 & Pengamat 1 & Pengamat 2 \\
\hline 1 & 4,2 & 4,25 & 3,84 & 4,00 \\
\hline 2 & 4,35 & 4,3 & 4,37 & 4,42 \\
\hline 3 & 3,8 & 4,05 & 4,21 & 4,16 \\
\hline 4 & 4,4 & 4,35 & 4,37 & 4,42 \\
\hline 5 & 3,95 & 4,05 & 4 & 4 \\
\hline Rata-rata & \multicolumn{2}{|c|}{4,17} & \multicolumn{2}{c|}{4,15} \\
\hline
\end{tabular}

Berdasarkan Tabel 6, dapat dilihat bahwa rata-rata nilai pengamatan keterlaksanaan pembelajaran selama 5 pertemuan untuk model discovery learning sebesar 4,17 sedangkan untuk model problem based learning sebesar 4,15 dimana nilai tersebut termasuk dalam kategori baik. Sehingga dapat disimpulkan bahwa penerapan model discovery learning maupun model problem based learning pada materi turunan di kelas XI SMA Negeri 3 Samarinda adalah baik. Namun meskipun sama-sama efektif digunakan, terdapat perbedaan efektivitas pada model discovery learning dan problem based learning pada hasil belajar siswa didukung oleh perbedaan nilai rata-rata setelah dilakukan tes kemampuan akhir pada penerapan model discovery learning sebesar 78,89 sedangkan nilai rata-rata pada penerapan model problem based learning sebesar 78,06. Hal ini menunjukkan bahwa model pembelajaran discovery learning memiliki efektivitas yang lebih tinggi dari pada model problem based learning.

Tabel 7. Hasil Analisis Anova Satu Arah

\begin{tabular}{|c|c|c|c|c|c|}
\hline \multicolumn{7}{|c|}{ Hasil Tes Kemampuan Akhir } \\
\hline & $\begin{array}{c}\text { Sum of } \\
\text { Squares }\end{array}$ & Df & $\begin{array}{c}\text { Mean } \\
\text { Square }\end{array}$ & $F$ & Sig. \\
\hline $\begin{array}{c}\text { Between } \\
\text { Groups }\end{array}$ & 4185.219 & 2 & 2092.610 & 21.005 & .000 \\
\hline Within Groups & 10161.829 & 102 & 99.626 & & \\
\hline Total & 14347.048 & 104 & & & \\
\hline
\end{tabular}


Hasil analisis data uji perbedaan rata-rata diperoleh nilai probabilitas $(\mathrm{p})$ sebesar 0,000 dengan taraf signifikan sebesar $5 \% \quad(\alpha=0,05)$. Hal ini menunjukkan bahwa nilai $\mathrm{p}<\alpha$ berarti $\mathrm{H}_{0}$ ditolak, sehingga dapat disimpulkan bahwa terdapat perbedaan antara kelompok yang diajar dengan model discovery learning, problem based learning, atau pembelajaran langsung.
Untuk mengetahui model pembelajaran manakah yang berbeda, maka uji dlanjutkan dengan menggunakan uji lanjut Least Significant Difference (LSD).

Uji LSD dilakukan dengan menggunakan bantuan program SPSS versi 24. Adapun hasil analisis uji LSD dapat dilihat pada Tabel 8 .

Tabel 8. Hasil Analisis Uji Least Significant Difference (LSD)

\begin{tabular}{|c|c|c|c|c|c|c|}
\hline \multicolumn{7}{|c|}{ Multiple Comparisons } \\
\hline \multirow{2}{*}{\multicolumn{7}{|c|}{$\begin{aligned} & \text { Dependent Variable: } \text { Hasil Tes Kemampuan Akhir } \\
& \text { LSD }\end{aligned}$}} \\
\hline & & & & & & \\
\hline \multirow{2}{*}{ (I) Kelompok } & \multirow{2}{*}{ (J) Kelompok } & \multirow{2}{*}{$\begin{array}{c}\text { Mean } \\
\text { Difference } \\
\text { (I-J) }\end{array}$} & \multirow{2}{*}{$\begin{array}{l}\text { Std. } \\
\text { Error }\end{array}$} & \multirow{2}{*}{ Sig. } & \multicolumn{2}{|c|}{$\begin{array}{l}\text { 95\% Confidence } \\
\text { Interval }\end{array}$} \\
\hline & & & & & $\begin{array}{l}\text { Lower } \\
\text { Bound }\end{array}$ & $\begin{array}{l}\text { Upper } \\
\text { Bound }\end{array}$ \\
\hline \multirow{2}{*}{$\begin{array}{l}\text { Discovery } \\
\text { learning }\end{array}$} & $\begin{array}{l}\text { Problem based } \\
\text { learning }\end{array}$ & 2.800 & 2.386 & .243 & -1.93 & 7.53 \\
\hline & $\begin{array}{l}\text { Pemb, } \\
\text { Langsung }\end{array}$ & $14.571^{*}$ & 2.386 & .000 & 9.84 & 19.30 \\
\hline \multirow{2}{*}{$\begin{array}{l}\text { Problem based } \\
\quad \text { learning }\end{array}$} & $\begin{array}{c}\text { Discovery } \\
\text { learning }\end{array}$ & -2.800 & 2.386 & .243 & -7.53 & 1.93 \\
\hline & Kelas Kontrol & $11.771^{*}$ & 2.386 & .000 & 7.04 & 16.50 \\
\hline \multirow{2}{*}{$\begin{array}{l}\text { Pemb, } \\
\text { Langsung }\end{array}$} & $\begin{array}{l}\text { Discovery } \\
\text { learning }\end{array}$ & $-14.571^{*}$ & 2.386 & .000 & -19.30 & -9.84 \\
\hline & $\begin{array}{l}\text { Problem based } \\
\text { learning }\end{array}$ & $-11.771^{*}$ & 2.386 & .000 & -16.50 & -7.04 \\
\hline
\end{tabular}

Berdasarkan Tabel 8, diketahui antara kelas yang diajar dengan model discovery learning dan problem based learning diperoleh nilai $\mathrm{p}>\alpha$ yaitu $0,243>0,05$ berarti $\mathrm{H}_{0}$ diterima, sehingga dapat disimpulkan bahwa tidak terdapat perbedaan antara kelompok yang diajar dengan model discovery learning dan kelompok yang diajar dengan model problem based learning. Tidak adanya perbedaan yang signifikan antara rata-rata hasil belajar siswa yang diajar dengan model discovery learning dan problem based learning disebabkan karena kedua model tersebut sama-sama menuntut siswa untuk lebih aktif dalam pembelajaran, siswa sama-sama diarahkan untuk menyelesaikan dan mempelajari sendiri materi yang sedang dipelajari. Guru tetap memberikan bantuan berupa arahan dan menjawab beberapa pertanyaan yang diajukan oleh siswa. Selebihnya siswa bersama kelompoknya menemukan dan menyelesaikan permasalahan yang disajikan. 
Hasil analisis antara kelas discovery learning dengan kelas pembelajaran langsung dan antara kelompok problem based learning dengan kelompok pembelajaran langsung diperoleh nilai $\mathrm{p}<$ $\alpha$ yaitu $0,000<0$, berarti $\mathrm{H}_{0}$ ditolak, sehingga dapat disimpulkan bahwa terdapat perbedaan antara kelompok discovery learning dengan kelompok pembelajaran langsung, dan antara kelompok problem based learning dengan kelompok pembelajaran langsung. Adanya perbedaan yang signifikan antara rata-rata hasil belajar siswa untuk kelas eksperimen (diajar dengan model discovery learning dan problem based learning) dan kelas kontrol (diajar dengan model pembelajaran langsung) karena pada kelas yang diajar dengan model pembelajaran langsung, siswa cenderung pasif, hanya menunggu guru menyampaikan materi dan memberikan tugas, sehingga pemahaman akan materi yang sedang dipelajari cenderung kurang.

Menurut Widyastuti dan Sri Adi (2018:879), siswa yang aktif belajar pasti siswa yang giat dan terus berusaha dalam belajar, selalu mencari tahu hal-hal baru tentang matematika, rajin bertanya jika kurang mengerti. Sehingga siswa menjadi banyak pengetahuan tentang matematika. Begitupun sebaliknya, siswa yang tidak aktif tidak akan berusaha mencari tahu dan bertanya jika kurang paham. Sehingga pengetahuannya pun akan kurang dan akhirnya berdampak pada hasil belajar matematika yang menurun. Maka dengan demikian dapat disimpulkan bahwa keaktifan siswa dapat mempengaruhi hasil belajar matematika siswa. Adapun cara yang dapat dilakukan agar peserta didik aktif dalam pembelajaran adalah dengan menerapkan model pembelajaran yang membuat siswa harus mencari tahu sendiri materi dan solusi dari permasalahan yang diberikan seperti model discovery learning dan problem based learning, dan memberi stimulus kepada siswa berupa pertanyaanpertanyaan dasar yang dapat mengarahkan siswa untuk bertanya.

\section{KESIMPULAN}

1. Ditinjau dari hasil belajar matematika siswa yang diajar dengan model pembelajaran discovery learning diperoleh rata-rata hasil belajar siswa lebih dari KKM yang ditetapkan oleh sekolah, yaitu 78,89>75 dengan persentase ketuntasan kelas sebesar $74,29 \%$, maka dapat dikatakan model pembelajaran discovery learning efektif diterapkan pada proses pembelajaran matematika khususnya materi turunan pada siswa kelas XI SMA Negeri 3 Samarinda Tahun Ajaran 2019/2020

2. Ditinjau dari hasil belajar matematika siswa yang diajar dengan model pembelajaran problem based learning diperoleh rata-rata hasil belajar siswa lebih dari KKM yang ditetapkan oleh sekolah, yaitu 76,09>75 dengan persentase ketuntasan kelas sebesar $51,43 \%$, maka dapat dikatakan model pembelajaran problem based learning efektif diterapkan pada proses pembelajaran matematika khususnya materi turunan pada siswa kelas XI SMA Negeri 3 Samarinda Tahun Ajaran 2019/2020

3. Setelah dilakukan uji anava satu arah kemudian dilanjutkan dengan uji Least Significant Difference (LSD), diketahui 
bahwa tidak terdapat perbedaan yang signifikan hasil belajar matematika siswa antara kelas yang diajar dengan menggunakan model discovery learning dan kelas yang diajar dengan model problem based learning. Namun, terdapat perbedaan antara kelas yang diajar dengan pembelajaran langsung dengan kelas yang diajar dengan model discovery learning dan problem based learning.

\section{DAFTAR PUSTAKA}

Kemendikbud. (2017). Model-Model Pembelajaran. Jakarta: Kemendikbud

Kurniawan, O., dan Noviana, E. (2017). Penerapan Kurikulum 2013 Dalam Meningkatkan Keterampilan, Sikap, dan Pengetahuan. Primary : Program Studi Pendidikan Guru Sekolah Dasar, 6(2): 389-396.

Nurochim, S.R., dan Prihatnani, E. (2018). Perbedaan Penerapan Problem Based Learning Dan Discovery Learning Ditinjau Dari Hasil Belajar Matematika Siswa Kelas VIII SMP N 8 Salatiga. Jurnal Mitra Pendidikan, 2(1),134-147.

Sitio, D.R., dan Sitio, F. (2016). Perbedaan Hasil Belajar Matematika Siswa yang Diajar dengan Model Pembelajaran Kooperatif Tipe Jigsaw dan STAD Pada Materi Turunan Di Kelas XI IPA SMA N 1 Girsang Sipangan Bolon. Prosiding Semnastika Unmed.

Suminar, S.O., dan Meilani, R.I. (2016). Pengaruh model pembelajaran Discovery learning dan Problem based learning terhadap prestasi belajar peserta didik. Jurnal
Pendidikan Manajemen Perkantoran, 1(1) , 80-89.

https://doi.org/10.17509/jpm.v1i1.3339

Susilawati, S., dan Hidayat, R. (2016). Penerapan Model Pembelajaran Scientific Untuk Meningkatkan Kemampuan Berpikir Kritis Matematis dan Self Concept Siswa MTs. Pythagoras: Jurnal Program Studi Pendidikan Matematika, 5(1): 59-65.

Widyastuti, E., dan Widodo, S.A. (2018). Hubungan Antara Minat Belajar Matematika Keaktifan Siswa Dan Fasilitas Belajar Di Sekolah Dengan Prestasi Belajar Matematika Siswa Kelas X SMK Se-kecamatan Umbulharjo. Prosiding Seminar Nasional Etnomatnesia, 873-881.

Widyoko, E.P. (2012). Teknik Penyusunan Instrumen Penelitian. Yogyakarta: Pustaka Pelajar. 